\title{
FREEDOM OF SPEECH IN INDONESIAN PRESS: INTERNATIONAL HUMAN RIGHTS PERSPECTIVE
}

\author{
Clara Staples \\ Law Schools, Faculty of Laws, Humanities and Arts \\ University of Wollongong \\ Email: cs471@uowmail.edu.au
}

\begin{abstract}
This paper will firstly examine the international framework of human rights law and its guidelines for safeguarding the right to freedom of speech in the press. Secondly, it will describe the constitutional and other legal rights protecting freedom of speech in Indonesia and assess their compatibility with the right to freedom of speech under the international human rights law framework. Thirdly it will consider the impact of Indonesia's constitutional law and criminal and civil law, including sedition and defamation laws, and finally media ownership, on the interpretation and scope of the right to freedom of speech in the press. Consideration of these laws will be integrated with a discussion of judicial processes. This discussion will be used to determine how and in what circumstances the constitutional right to freedom of speech in the press may be facilitated or enabled, or on the other hand, limited, overridden or curtailed in Indonesia. Conclusions will then be drawn regarding the strengths and weaknesses of Indonesian laws in safeguarding the right to freedom of speech in the press and the democratic implications from an international human rights perspective. This inquiry will be restricted to Indonesian laws in existence during the post-New Order period of 1998 to the present, and to the information and analysis provided by English-language sources.
\end{abstract}

Keywords: freedom of speech, human rights, Indonesia, freedom of expression

\section{INTRODUCTION}

Freedom of speech is recognised as an international human right by the United Nations ('the UN') who 'play a vital role in promoting and protecting human rights worldwide. ${ }^{1}$ In 1948 the UN General Assembly adopted the Universal Declaration of Human Rights

1 Sangsuvan, Kitsuron, 'Balancing Freedom of Speech on the Internet Under International Law' (2014) 39 North Carolina Journal of International Law and Commercial Regulation 701, 707-8. ('the Declaration') setting out 'fundamental human rights to be universally protected' and aiming for 'a common standard of achievements for all peoples and all nations.' ${ }^{2}$ The right to freedom of expression is included as one of the thirty articles outlining universal rights contained in the

\footnotetext{
2 The United Nations, The Universal Declaration of Human Rights $<$ http://www.un.org/en/universal-declarationhuman-rights/>.
} 
Declaration. ${ }^{3}$ Article 19 of the International Covenant on Civil and Political Rights of 1966 ('the ICCPR') is based on the wording and sentiment of Article 19 of the Declaration ${ }^{4}$ and forms part of the International Bill of Human Rights which aims to guarantee civil and political rights. ${ }^{5}$ In seeking that the articulated rights be 'accepted by people of all nations and cultures' ${ }^{6}$ the UN encourage the homogenisation of law across the globe. On account of such aims Article 19 of the ICCPR is presumed for the purpose of this essay to articulate the ideal global standard of the right to freedom of speech. It provides that '[e]veryone shall have the right to hold opinion without interference' and that '[e]veryone shall have the right to freedom of expression; this right shall include freedom to seek, receive and import information and ideas of all kinds, regardless of frontiers, either orally, in writing or in print, in the form of art, or through any other media of his choice.' 7 In accordance with the wording of Article

${ }^{3}$ The Universal Declaration of Human Rights ('UDHR'), GA Res 217A (III) UN GAOR, $3^{\text {rd }}$ sess, $183^{\text {rd }}$ plen mtg, UN Doc A/810 (10 December1948) art 1.

${ }^{4}$ UDHR, UN Doc A/810, art 19.

${ }^{5}$ Sangsuvan, above $n$ 2, 710.

${ }^{6}$ Ibid 709.

${ }^{7}$ UDHR, UN Doc A/810, art 19
19 the right to freedom of speech thereby extends to the press and media platforms online.

Whilst not intended to be 'binding on states as part of positive international law, ${ }^{8}$ the Declaration is according to American academic Kitsuron Sangsuvan accepted as providing a 'foundation of international human rights law.' 9 Furthermore, as academic Dr Nadirsyah Hosen asserts, the endorsement of the Declaration by virtually all states has enabled it to acquire 'customary international law' status. ${ }^{10}$ In order however for the right to freedom of speech to be legally recongised within one's own state, the domestic legal system of that state must legally acknowledge and protect that right. ${ }^{11}$ Sangsuvan thereby observes that 'the domestic legal system provides the principal legal protection of freedom of speech.' 12 The right to freedom of speech in the press is not strictly guaranteed by international law, but rather, dependent on the law of domestic legal systems and the

8 Sangsuvon, above n 2, 709.

${ }^{9}$ Ibid 710.

${ }^{10}$ Nadirsyah Hosen, 'Human rights and press freedom' in Nadirsyah Hosen, Human Rights, Politics and Corruption in Indonesia: a critical reflection on the post Soeharto Era (Dordrecht 2010) 141, 143.

${ }^{11}$ Sangsuvon, above n 2, 709

${ }^{12}$ Ibid. 
adherence of that system to the principles of international human rights law.

Creating a degree of uniformity to laws regulating press freedom across legal systems in accordance with UN standards or guidelines could arguably contribute to the democratisation of the press in Indonesia. Indonesia's transition to democracy since the fall of the Suharto government in 1998 has been discussed extensively in international legal commentary. ${ }^{13}$ In examining press freedom in Indonesia, American academic Dr Robert McChesney has noted 'a crucial aspect of viable journalism in a democracy is its ability to give rigorous account of who is in power and who wishes to be in power. ${ }^{\prime 4}$ This is how, according to Indian academic Naveen Mishra, news media ensures adequate checks and balances are kept on national government and the head of state,

\footnotetext{
${ }^{13}$ See, eg, Ross Tapsell, 'Politics and Press in Indonesia' (2012) 39(2) Media Asia 109; Naveen K. Mishra, 'Governmental Threats for Media Freedom: comparative study of Asian countries' (2008) 69(1) The Indian Journal of Political Science 149; Nadirsyah Hosen, Human Rights, Politics and Corruption in Indonesia: a critical reflection on the post Soeharto Era (Dordrecht 2010); Royan, Naomita, 'Increasing Press Freedom in Indonesia: the Abolition of the Lese Majeste and 'Hate-Sowing Provisions' (2008) 10 Australian Journal of Asian Law 291.

${ }^{14}$ Quoted in Tapsell, above n 1, 109.
}

thereby fulfilling its role as the 'Fourth estate' of democracy. ${ }^{15}$

This paper seeks to analyse Freedom of speech in Indonesia from the perspectives of human rights. Constitutional and other legal rights protecting freedom of speech in Indonesia will be analysed under the international human rights law framework. It will also consider the impact of Indonesia's constitutional law and criminal and civil law, including sedition and defamation laws, and finally media ownership, on the interpretation and scope of the right to freedom of speech in the press. Consideration of these laws will be integrated with a discussion of judicial processes.

\section{METHODOLOGY}

This paper uses juridicalnormative method, including reviewing and analysing the rules of freedom of speech in Indonesia. Relevant laws and policy is analysed.

The approach used in this paper is statute approach. Constitutional protection on freedom of speech will be

15 Naveen K. Mishra, 'Governmental Threats for Media Freedom: comparative study of Asian countries' (2008) 69(1) The Indian Journal of Political Science 149, 149. 
analysed from human rights point of view. It begins with the brief description on international legal framework on freedom of speech and human rights. Furthermore, Indonesian constitution and freedom of speech law will be analysed in the framework of international human rights laws.

\section{III.RESULT AND DISCUSSION} CONSTITUTIONAL SAFEGUARDS TO THE RIGHT TO FREEDOM OF SPEECH IN INDONESIAN PRESS

Hosen recognises that the right to express an opinion is honoured in the 1945 Constitution of the Republic of Indonesia ('the Constitution') encapsulated in Article 28. ${ }^{16}$ However Article 28 of the Constitution does not outline or identify the extent to which the right is protected by law. Rather the provision states that the '[f]reedom to unite and gather, express opinions orally and in writing and the others shall be stipulated by virtue of law' ${ }^{17}$ (emphasis added). The qualifications to the right to freedom of speech under the ICCPR are explicitly listed under Article 19(3) and 'shall only be such as are provided by law and are necessary: (a) For respect of

\footnotetext{
${ }^{16}$ Hosen, above $\mathrm{n} 11,148$.

17 The 1945 Constitution of the Republic of Indonesia art 19.
}

the rights or reputations of others; (b) For the protection of national security or of public order or of public health or morals.' ${ }^{18}$ Although a member of the United Nations since 28 September $1950^{19}$ Indonesia was relatively late in its accession to the ICCPR. The ICCPR entered into force on 23 March 1976 with Indonesia assenting nearly thirty years later on 23 February 2006. ${ }^{20}$ The Indonesian government therefore had prior to its ratification of the ICCPR, and still maintains by virtue of its domestic law, wide scope to legislate to restrict the constitutional right to freedom of expression under Article 28 for matters beyond those listed in Article 19(3) of the ICCPR. This has arguably created weaknesses in safeguarding the constitutional right of Indonesian journalists to express free speech, for example by restricting that

${ }^{18}$ The International Covenant on Civil and Political Rights ('ICCPR') GA res 2200A, UN GOAR, $21^{\text {st }}$ sess, Supp No (16) 52, UN Doc A/6316 (1966) art 19.

19 The United Nations, United Nations Member States $<$ http://www.un.org/press/en/2006/org1469.doc. htm>.

20 The United Nations Treaty Collection, International Covenant on Civil and Political Rights $<$ https://treaties.un.org/Pages/ViewDetails.aspx ?src=IND\&mtdsg no=IV-

4\&chapter=4\&lang=en>; Law No 12 of 2005 of the Republic of Indonesia on the Confirmation (Pengesahan) of the International Covenant on Civil and Political Rights. 
right through sedition laws, as illustrated by case examples discussed below.

The second amendment to the Constitution in 2000 expanded and clarified the right to freedom of speech with the addition of chapter XA on Human Rights. Amendments included the addition of Article 28(3) which entitles everyone to unite, gather and express opinions, and Article 28F which states '[e]veryone shall be entitled to communicate and obtain information to develop their personality and social setting, and to find, obtain, have, keep, process and give information with any means of channel available.' ${ }^{21}$ This phrasing resembles Article 19 of the $I C C P R$ in its recognition that the right to freedom of speech exists on 'any means of channel' and thereby includes expressions of free speech online. Constitutional amendment thereby helped define, clarify and expand the right to freedom of expression, strengthening the legal protection of free speech in the press.

\section{CIVIL LAW PROTECTION OF THE RIGHT TO FREEDOM OF SPEECH IN INDONESIAN PRESS}

21 The 1945 Constitution of the Republic of Indonesia art 28F.
Law No 9/1998 of the Republic of Indonesia on Freedom of Expression, introduced in the post-New Order period, recognises freedom of speech as both a right and a responsibility that must be exercised in a 'responsible way. ${ }^{22}$ The right to freedom of speech for journalists specifically is further safeguarded by the Law No. 40/1999 of the Republic of Indonesia on the Press ('the Press Law'). The philosophical basis of the Press Law describes press freedom as 'the utmost important element in creating a democratic society, nation and state to assure the freedom of expressing ideas and opinion as stated in Article 28 of the Indonesian Constitution of 1945 must be guaranteed.' 23 This philosophical basis is reinforced by the following provisions:

a. Article 2 which states 'the freedom of the press is one of the embodiments of sovereignty of the people based upon principles of democracy, justice and supremacy of the law';

b. Article 3 which outlines the social control function of the

${ }^{22}$ Law No 9/1998 of the Republic of Indonesia on Freedom of Expression; in Hosen, above n 11, 162.

${ }^{23}$ Law No 40/1999 of the Republic of Indonesia on the Press. 
press, enabling it to criticise government policies and provide public debate on political issues, thereby '[opening] the door for the press to act as the fourth estate' of democracy; ${ }^{24}$

c. Article 4 which states press freedom is guaranteed as a basic right for citizens and should be 'free from censorship and is not subject to publication and broadcasting bans';25 and

d. Article 6 which states that the role of the press is to 'enforce basic democratic principles, promote the embodiment of the supremacy of the law and human rights, while at the same time respecting diversity.' 26

The aim of using the Press Law to facilitate freedom of speech and contribute to the creation of a democratic society mirrors decisions made in the European Court of Human Rights, which have interpreted the right to freedom of speech as 'one of the basic conditions for [the] progress of a democratic society and for the

\footnotetext{
${ }^{24}$ Hosen, above n 11, 201.

${ }^{25}$ Ibid 200-1.

26 The 1945 Constitution of the Republic of Indonesia arts 2-4, 6.
}

development of every man.' 27 Contributions were made to the drafting of the Press Law Bill by international organisations, including legal experts from the United Nations Educational, Scientific and Cultural Organization ('UNESCO') and from Article XIX, a British NGO whose activities focus on safeguarding the right to freedom of expression. ${ }^{28}$ The Press Law is supported by Law No. 39/1999 of the Republic of Indonesia on Human Rights ('Law No. 39/1999 on Human Rights'), that acknowledges the 'responsibilities and obligation of the Government in the promotion and protection of human rights.' 29 Specifically in relation to freedom of speech, Article 19 of Law No. 39/1999 on Human Rights 'protects the right to seek, own, store and disseminate information, through any channel. ${ }^{30}$ Law No. 39/1999 on Human Rights also serves to prop up Articles 19-21 of the 1998 MPR Human Rights Charter which 'protects citizens' rights to freedom of expression without interference, and to seek, receive and impart information and ideas, through

\footnotetext{
${ }^{27}$ Handyside $v$ United Kingdom (1976) 24 ECHR (ser. A) 23.

${ }^{28}$ Hosen, above n 11, 198.

${ }^{29}$ Ibid 162.

${ }^{30}$ Law No 39/1999 of the Republic of Indonesia on Human Rights art 14.
} 
any media.' ${ }^{31}$ The constitutional right to freedom of speech in Indonesia is thereby supported through numerous civil law provisions. The rights to freedom of speech conferred by the Constitution and under Indonesia’s civil laws are in theory compatible with the international right to freedom of speech as articulated by the UN.

\section{THE ESTABLISHMENT OF THE CONSTITUTIONAL COURT AND ITS JUDICIAL REVIEW} FUNCTION

The establishment of the Indonesia’s Constitutional Court which commenced operation along with its judicial review function in 2003, by virtue of the fourth amendment to the Constitution in 2002 and the addition of Article 24C, strengthens the legal protection of the constitutional right to freedom of speech. ${ }^{32}$ The Constitutional Court provides a legal avenue through which members of the press and other individuals can assert their constitutional right to freedom of

31 Stipulation made by the National Assembly of the Consultative Council of the Republic of Indonesia No. XVII/MPR/1998 on Human Rights; Hosen, above n 11, 159.

32 Naomita Royan, 'Increasing Press Freedom in Indonesia: the Abolition of the Lese Majeste and 'Hate-Sowing Provisions' (2008) 10 Australian Journal of Asian Law 291, 297. speech when legislation is perceived to hinder or obstruct that right. The Constitution did not in its original form create a Constitutional Court and until 2002 'Indonesian courts did not have jurisdiction to exercise judicial review.' 33 The new standing given to parties whose constitutional rights are adversely affected by civil or criminal laws, ${ }^{34}$ to challenge the constitutionality of those laws, is therefore a significant improvement and strength in safeguarding the right to freedom of speech in Indonesian press.

\section{THE IMPACT OF SEDITION} LAWS ON THE RIGHT TO FREEDOM OF SPEECH IN INDONESIAN PRESS

In 2006 and 2007 the judicial review function of the Constitutional Court was used to hear two significant cases, Constitutional Court Decision No 012- 022/PUU-IV/2006 ('Sudjana and Lubis') and Constitutional Court Decision No 6/PUU-V/2007 ('Panji'), that challenged sedition laws which operated to restrict freedom of speech in order to enhance the President's 'ability to govern peacefully., ${ }^{35}$ Sedition laws

\footnotetext{
${ }^{33}$ Ibid 296-7.

${ }^{34}$ Ibid 297.

${ }^{35}$ Ibid 293.
} 
are in this regard distinct from defamation laws which proscribe expressions that cause harm to an individual's reputation. 36 Instead sedition laws proscribe 'words or conduct deemed to incite discontent or rebellion against the authority of the state.' ${ }^{37}$ Whilst the ICCPR recognises the qualification to freedom of speech for the purpose of maintaining public order in accordance with Article 19(3), it is argued by Australian legal practitioner Naomita Royan that the sedition laws are 'questionable, at the very least, in countries founded on democratic principles.' ${ }^{38}$ Royan argues that '[i]n such nations, a ruler is the people's representative and, as such, does not possess a "divine right" but is held accountable to the electorate, the members of which are entitled to criticise and question their elected representatives.' 39 Sedition laws are also in antithesis to the democratic purpose of the Press Laws, which as previously discussed, recognise that 'the utmost important element in creating a democratic society, nation and state [is] to assure the freedom of expressing ideas and opinions' by guaranteeing or safeguarding the constitutional right to freedom of speech in the press. ${ }^{40}$

The existence of sedition laws undeniably weakens the ability to assert one's right to freedom of speech in the press. In Sudjana and Lubis a political activist and a lawyer both charged with sedition argued that the Indonesia Criminal Code (Kitab Undang-undang Hukum Pidana) ('Criminal Code’) Articles 134, 136 and 137, which criminalised insults made against the President and Vice-President, were unconstitutional. ${ }^{41}$ While Article 134 had broad application in applying to anyone who deliberately insulted the President or Vice-President, Article 137 as noted by Royan 'directly targeted journalists and the press' by criminalising dissemination with the intention of publicising those insults. ${ }^{42}$ Under these provisions those who reported and published any criticisms others made of the President or VicePresident in the press could be prosecuted, and if found guilty, face up to six years imprisonment. Furthermore, Criminal Code Article

\footnotetext{
${ }^{40}$ Law No 40/1999 of the Republic of Indonesia on the Press.

${ }^{41}$ Royan, above n 33, 298.

42 Ibid 294-5.
} 
137(2) prohibited 'repeat offenders who disseminated those views in the course of their occupations . . . "from exercising the aforesaid profession.”, 43 Journalists and editors therefore risked exclusion from the profession if found guilty of more than one sedition charge, significantly curbing their ability to exert the right to free speech on political matters involving the heads of state.

Sudjana and Lubis is a landmark decision enabling press freedom in Indonesia, following the Constitutional Court's finding that the Criminal Code provisions were 'remnants of Indonesia colonial past' under Dutch rule, originally intended to snare 'prominent figures of the independence movement' in Indonesia and therefore 'contradictory to the position of Indonesia as an independent and sovereign state.' 44 The specific constitutional provisions that the Constitutional Court majority ruled had been offended by the Criminal Code were Article 27(1) concerning equality before the law, Article 28F concerning the ability to communicate and obtain information, and Article 28E(2)-(3) concerning the freedom to express

\footnotetext{
43 Ibid 295.

44 Constitutional Court Decision No 012- 022/PUU-IV/2006 at [3.18.6].
}

opinions and attitudes. ${ }^{45}$ The court found that the criminalisation of insults against the President and Vice-President under Criminal Code Articles 134, 136 and 137 were unconstitutional and 'contrary to Indonesia's democracy. ${ }^{46}$ Interestingly, Article 28 of the Constitution was not argued or held to be infringed, providing support for the argument that Article 28 as a stand alone provision provides weak or limited protection for freedom of speech in the press, as posited earlier in this paper. The decision in Sudjana and Lubis confirms the significance of the Constitutional amendments made in 2000, with the additional constitutional Articles 28F and 28E(2)-(3) being used by Sudjana and Lubis to assert and enforce their rights to freedom of speech in the press. The Court's decision in Sudjana and Lubis also highlights the strength of judicial review in safeguarding the right to freedom of speech in the press.

In the 2007 case of Panji the constitutionality of sedition provisions contained in Articles 154 and 155 of the Criminal Code, which criminalised 'public expression of feelings of hostility, hatred, or contempt toward the

\footnotetext{
${ }^{45}$ Royan, above n 33, 291.

${ }^{46}$ Ibid 290.
} 
government,' were challenged. 47 Similarly to Article 134, Article 154 of the Criminal Code applied to anyone who publicly expressed feelings of hostility, hatred or contempt towards the Indonesian government. Meanwhile Article 155(1) criminalised dissemination with the intention of publicizing those views, thus explicitly targeting members of the press. ${ }^{48}$ It was therefore submitted by applicant Panji that Articles 154 and 155 had the 'potential to repress freedom of the press, because these provisions were available to silence those who criticised the Indonesian government, as well as those who reported criticism of it.' 49 Furthermore, as noted by Royan, Articles 134 and 154 both lacked a mens rea element. ${ }^{50}$ Journalists could thereby be found liable without having 'actual or intended consequences to the [use of the] insult or expression of hostility. ${ }^{51}$

Additionally there was not legislative definition outlining what constituted an 'insult,' and in a legal system that does not apply the principles of stare decises no uniform

\footnotetext{
${ }^{47}$ Ibid.

48 Ibid.

${ }^{49}$ Ibid 294.

${ }^{50}$ Ibid.

${ }^{51}$ Ibid.
}

definition could be formulated and applied by the courts in latter cases. ${ }^{52}$ As further argued by Royan, '[t]he lack of definitions in the law enabled it to undermine the very operation of the media, as journalists would necessarily be reluctant to criticise the leaders of the country without knowing when that criticism was seditious.' 53 In addition, there was reluctance by the press to report popular criticism of the state's actions ${ }^{54}$ or the views of 'political activists and other politicians. ${ }^{55}$

Panji proved to be a landmark decision signaling a move towards a more democratic press with the Constitutional Court ruling that Articles 154 and 155 of the Criminal Code did in fact infringe the constitutional right to freedom of expression under Article 28 as well as freedom of expression under Article 28E(2)-(3). ${ }^{56}$ As a result of the decisions in Panji and Sudjana and Lubis Criminal Code Articles 134, 136, 137, 154 and 155 no longer have the

52 Ibid.

53 Ibid 295.

54 Human Rights Watch, Turning Critics into Criminals: the human rights consequences of criminal defamation in Indonesia (3 May 2010) < https:/www.hrw.org/report/2010/05/03/turningcritics-criminals/human-rights-consequencescriminal-defamation-law $>$.

${ }^{55}$ Royan, above n 33, 295.

56 Ibid 291. 
force of law. ${ }^{57}$ Royan concludes that the judicial defeat of these provisions '[discourages] media self-censorship, [and] demonstrate[s] that the country is shifting away from its repressive colonial and post-independence, authoritarian legacy towards a more open, rights-based democracy, with growing space for the media.' 58

\section{THE IMPACT OF DEFAMATION} LAWS ON THE RIGHT TO FREEDOM OF SPEECH IN INDONESIAN PRESS

In practice however numerous Criminal Code provisions continue to limit the right to freedom of speech in the press. This is despite the significant developments towards a more democratic press signaled by the enactment and commencement of the Press Law in 1999. Under the Press Law Article 15 granted the Indonesian Press Council independence from the government in order to develop freedom of the press and expand the existence of the national press. ${ }^{59}$ It also conferred on the Council the power to adjudicate all media disputes by 'providing

\footnotetext{
${ }^{57}$ Ibid 290-1.

${ }^{58}$ Ibid 292.

${ }^{59}$ Law No 40/1999 of the Republic of Indonesia on Freedom of the Press art 15(1).
}

consideration and finding settlement to public grievances on cases related to press coverage or news.' 60 This function was reinforced by a Supreme Court ruling in 2005. ${ }^{61}$ However, recent cases examined by Freedom House suggest that instead of bringing defamation charges under the Press Law, authorities now 'undermine the council's mandate' 62 by bringing defamation charges to the courts under other laws which can result in the imposition of harsh criminal penalties and extensive periods of imprisonment. Whilst the ICCPR recognises respect for the right to reputation as a qualification on expression of free speech in accordance with Article 19, an overwhelming number of defamation offences continue to exist in Indonesia's criminal code. Such provisions numbered more than 40 in 2015, and are sufficiently vague in their definition to pose difficulties for journalists in knowing when a criticism will constitute a defamatory expression. ${ }^{63}$

\footnotetext{
${ }^{60}$ Ibid $\operatorname{art} 15(2)(d)$.

61 Freedom House, Freedom of the Press: Indonesia (2012)

$<$ https://freedomhouse.org/report/freedompress/2012/indonesia $>$.

${ }^{62}$ Freedom House, Freedom of the Press: Indonesia (2015)

$<$ https://freedomhouse.org/report/freedompress/2015/indonesia $>$.

${ }^{63}$ Ibid.
} 
As explained by Royan, defamation laws concerning reputation are distinct from sedition laws discussed above. ${ }^{64}$ However, in justifying their decision in the case of Eggi and Pandapotan, the Constitutional Court noted that defamation provisions in Articles 310-321 of the Criminal Code can still be used in situations where the President or Vice-President's personal reputation is damaged, while Article 207 which 'criminalises insults to rulers and public bodies, [can] be used in situations where the President or VicePresident is insulted in his or her official capacity.' ${ }^{65}$ There is therefore some over lap between the sedition laws now repealed and defamation provisions still in existence. The obvious utility in limiting the number of existing criminal provisions dealing with the same or similar criminal acts could, as indicated by the Court's reasoning, have contributed to the Court's decision to annul the sedition provisions. As the constitutionality of defamation Articles 207, 310, 311 and 316 of the Criminal Code was upheld in 2008 Decision No $14 /$ PUU-VI/2008 ${ }^{66}$ the practical impact

\footnotetext{
${ }^{64}$ Royan, above n 33, 293.

65 Constitutional Court Decision No 012- 022/PUU-IV/2006 at 60 in Royan, above n 34, 299

${ }^{66}$ Royan, above n 33, 304.
}

of the repeal of sedition Articles 134, 136, 137, 154 and 155 is limited. Members of the press can still have their right to freedom of speech denied and face criminal prosecution for insulting or criticising rulers and public bodies, including the President or VicePresident, or acts that occur in their official capacity as the heads of state. ${ }^{67}$

The Human Rights Watch reasonably asserts that '[d]efamation laws exist to protect individuals from having their reputations intentionally and falsely tarnished by others. ${ }^{68}$ Laws proscribing defamatory speech theoretically fall within the 'necessary and narrowly drawn' ${ }^{69}$ qualifications to free speech recommended by the ICCPR under Article $19 .{ }^{70}$ It is common in many countries for civil defamation laws to enable victims of defamatory speech to receive monetary compensation or an apology, however Indonesia imposes additional criminal

\footnotetext{
67 Criminal Code (Kitab Undangundang Hukum Pidana) art 207.

68 Human Rights Watch, Turning Critics into Criminals: the human rights consequences of criminal defamation in Indonesia (3 May 2010) <https://www.hrw.org/report/2010/05/03/turnin g-critics-criminals/human-rights-consequencescriminal-defamation-law $>$.

${ }^{69}$ Ibid.

${ }^{70}$ The ICCPR, UN Doc A/6316, art 19.
} 
penalties for 'reputational harm.' ${ }^{71}$ As Indonesia's defamation provisions are complaint-driven, the complainant can elect at their discretion whether to pursue a civil or criminal claim, or both, against the alleged wrongdoer. ${ }^{72}$ In effect criminal and civil provisions proscribe the same offence, the only difference being the penalty imposed, which for criminal offences is up to six years imprisonment in the case of defamatory speech shared over the internet, ${ }^{73}$ as opposed to the remedies of compensatory payment or measures to publicly retract the defamatory speech which apply in civil cases. ${ }^{74}$

As the discretion lies in the hands of the complainant to choose which avenue to prosecute insulting speech, the protection of freedom of speech in the press is weakened. Deliberate 'insulting' speech, even if the statements made are true, against public officials acting in an official capacity carries a penalty of up to 18

\footnotetext{
${ }^{71}$ Turning Critics into Criminals: the human rights consequences of criminal defamation in Indonesia, above n 69.

${ }^{72}$ Royan, above $n$ 33, 304.

${ }^{73}$ Law No 11/2008 of the Republic of Indonesia on Electronic information and transaction.

${ }^{74}$ Turning Critics into Criminals: the human rights consequences of criminal defamation in Indonesia, above n 69.
}

months imprisonment. ${ }^{75}$ As noted by the Human Right Watch, this has led to a tendency for politicians to elect to lay criminal defamation charges against journalists who are critical of their conduct or views. ${ }^{76}$

The Alliance of Independent Journalists ('AJI') has also voiced concerns about the increasing use of Law No 11/2008 of the Republic of Indonesia on Electronic Information and Transaction ('ITE Law') 'to muzzle internet users with spurious defamation claims. According to Indonesia Corruption Watch, as of October 2014, 71 people had faced defamation charges under Article 27 (3) of the ITE Law since it was passed, with 40 cases in 2014.' 77 As discussed, penalties for defamatory statements posted or shared online carries a penalty of up to six years imprisonment. ${ }^{78}$ The impact of these defamation laws may be selfcensorship by members of the press, if they remain fearful of the risk of imprisonment or loss of employment to report on pertinent political issues, or

\footnotetext{
75 Ibid.

76 Ibid.

${ }^{77}$ Freedom of the Press: Indonesia, above n 63 .

${ }^{78}$ Ibid.
} 
news involving political figures including the heads of state. ${ }^{79}$

In a recent article the Human Rights Watch has argued that 'criminal penalties are always disproportionate punishments for reputational harm and should be abolished. ${ }^{80}$ This position is supported by the fact that civil defamation and criminal incitement laws already exist, and may be regarded as 'sufficient for the purpose of protecting people's reputations and maintaining public order' whilst at the same time 'written and implemented in ways that provide appropriate protections for freedom of expression., 81

Further supporting the argument for the abolishment of criminal defamation provisions is the disjunction between the prison terms that apply for defamation under the Criminal Code in comparison with the criminal penalties that apply for hindering a journalist's right to free speech under the Press Law. Violation of Article 18 of the Press Law, which applies to 'anyone who intentionally impedes the national press in exercising that press freedom,

\footnotetext{
${ }^{79}$ Turning Critics into Criminals: the human rights consequences of criminal defamation in Indonesia, above n 69.

${ }^{80}$ Ibid.

${ }^{81}$ Ibid.
}

as provided in article 4' by imposing 'censorship, banning or restriction of broadcasting,' will result in a two year imprisonment or up to 500 million rupiah fine. ${ }^{82}$ In comparison, the penalty for defamation under Article 310 of the Criminal Code is four years imprisonment, this is double the penalty imposed for hindering the right of the press to express free speech. ${ }^{83}$ The imposition of harsher penalties for defamatory speech in comparison to the unlawful censorship of free speech indicates that the law prioritises control of press content, over the facilitation of the right to freedom of speech in the press. The Human Rights Watch points out that 'the application of criminal defamation laws in Indonesia gives rise to a damaging, chilling effect on speech central to the effective functioning of a democratic society. It can seriously undermine the work of local NGOs and community-level actors working to combat corruption' 84 and thereby weakens the protection of the right to free speech in the press.

\section{MEDIA OWNERSHIP AND REGULATION}

\footnotetext{
${ }^{82}$ Hosen, above n 11, 205.

83 Ibid 209.

${ }^{84}$ Turning Critics into Criminals: the human rights consequences of criminal defamation in Indonesia, above n 69.
} 
In an article published in 2010 , Hosen commented that '[a]lthough [the Press Law] introduced a new paradigm, "professional freedom of the press", it is apparent that full implementation of these rules and principles is a still a long way off.' 85 This paradigm is encapsulated in Article (c) of the Statement of the Philosophical Base for the Press Law 1999 which reads: 'the national press as the media for mass communication, information dissemination, and shaping public's opinion, must be able to perform at its best according to its principles, functions, rights, obligations and roles based upon the professional freedom of the press, guaranteed and protected by the law and free from any interference and intrusion.'

The Press Law states that these values are in accordance with Article 5 item (1), Article 20 item (1), Article 27, and Article 28 of the Constitution and the Indonesia's Human Rights policy. ${ }^{86}$ One of the weaknesses however in the realisation of this paradigm is the lack of legal regulation over media

${ }^{85}$ Hosen, above n 11, 209.

${ }^{86}$ Law No 40/1999 of the Republic of Indonesia on Freedom of the Press; Stipulation made by the National Assembly of the Consultative Council of the Republic of Indonesia No. XVII/MPR/1998. ownership which effects professionalism and quality of the press. According to Australian academic Dr Ross Tapsell, control of the flow of news since the fall of the Suharto regime in 1998 'has shifted from the government and military to an oligarchic group of media owners with political and business interests.' 87 Nonprofit groups Hivos Southeast Asia and the Center for Innovation, Policy and Governance conducted a study in 2011 that found 'nearly all of the 12 most prominent media companies had ties to political parties in some respect. These 12 companies also own the country's 10 major national television stations and five of the six major newspapers.' 88 This has led to what Tapsell describes as self-censorship as a professional practice in Indonesian journalism. ${ }^{89}$ Freedom House confirms that media coverage of the 2014 Presidential election was indicative of 'the ability of political parties, large corporations, and powerful individuals to control media content, with major media outlets openly reflecting the

\footnotetext{
${ }^{87}$ Tapsell, Ross, 'Old Tricks in a New Era: Self-Censorship in Indonesian Journalism' (2012) 36 Asian Studies Review 227, 228.

${ }^{88}$ Freedom of the Press: Indonesia , above n 63 .

${ }^{89}$ Tapsell, above n 88, 288.
} 
political affiliations of their owners. 90 Journalists interviewed at the Surabaya Post, bought by 2014 Presidential candidate for the Golkar party Aburizal Bakrie in 2008 and managed by executives of his subsidiary company Lapindo, explained how their autonomy had been limited since this change in ownership, due to 'pressure or fears of being reprimanded or fired' if they reported news critical of the 2014 Presidential candidate or companies owned by him. ${ }^{91}$ Tapsell recognises the pressure put on journalists to censor news coverage as the 'antithesis to journalism as crucial to a functioning democracy which Indonesia has embarked upon since 1999. ${ }^{92}$

One legal solution to the covert pressure placed on journalists which undermines the_aims of the Press Law would be to reform what Tapsell describes as the 'weak laws which do not regulate the system of ownership. ${ }^{93}$ Whilst print media is regulated through the press council and broadcast media licensed by the Ministry of Communication and Information Technology and the Indonesian

${ }^{90}$ Freedom of the Press: Indonesia , above $\mathrm{n} 63$.

91 Tapsell, above n 1, 110, 113-4.

92 Ibid.

${ }^{93}$ Ibid 100
Broadcasting Commission, ${ }^{94}$ there are no limits on the control and ownership of the press and distribution channels by political parties or politicians. By contrast, Taiwan amended its media laws in 2003 resulting in the ban of political parties and politicians from involvement or investment in private radio and TV stations. ${ }^{95} \mathrm{~A}$ similar reform in Indonesia, requiring political parties and members of parliament to sell out their stockholdings and relinquish their control of media channels, would arguably provide greater safeguards for freedom of speech and facilitate the democratisation of the press, as it did in Taiwan. ${ }^{96}$

\section{CONCLUSIONS}

The Indonesian press has indeed evolved since its 'de-politicised' state under Suharto's New Order regime. ${ }^{97}$ Legal reform in Indonesia in the postNew Order period has in theory strengthened the protection of the right to freedom of speech in the press. The above n 63.

${ }^{94}$ Freedom of the Press: Indonesia ,

95 Chen-Ling Hung, 'Media Control and Democratic Transition: Ongoing Threat to Press Freedom in Taiwan', (2013) 9(2) China Media Research 83, 87.

${ }^{96}$ Ibid.

${ }^{97}$ Hosen, above n 11, 155. 
2000 Constitutional amendments that expanded the constitutional right to freedom of speech, the creation of the Constitutional Court with its judicial review function, and the Constitutional Court decisions of Eggi and Pandapotan and Panji that found certain sedition provisions to be unconstitutional, mark what Royan describes as 'Indonesia’s continuing evolution towards the institutionalisation of far greater freedom of expression' in the press. ${ }^{98}$

However, in spite of Indonesia's progress towards a free press, President Joko Widodo made a speech to the legislature on 14 August 2015 lamenting the '[c]urrent tendencies that people feel they are ultimately free to behave and voice their opinions as they like. This is less productive when the media only pursues ratings instead of guiding the public to be virtuous and have a productive work culture. ${ }^{99}$ This sentiment echoes the justifications used to censor the press in the period of Suharto's New Order rule, when the media was perceived as the

\footnotetext{
${ }^{98}$ Royan, above n 33, 296.

99 'Jokowi told not to mess with press freedom', The Jakarta Post (online), 15 August 2015

<http://www.thejakartapost.com/news/2015/08/ 15/jokowi-told-not-mess-with-pressfreedom.html\#sthash.DblP2YaE.dpuf>.
}

'government's partner' in the process of nation building, and the right to freedom of speech in the press significantly curtailed. 100 It was reported in August 2015 that the Widodo government submitted a draft Criminal Code amendment to the House of Representatives that would make insulting the president a crime, 101 despite the annulment of that same provision by the Constitutional Court in Sudjana and Lubis in 2006. ${ }^{102}$

The democratisation process of the Indonesian press is not yet complete. Further changes can undoubtedly be made to strengthen the ability to manifest one's right to freedom of speech through the press, such as the introduction of media laws regulating and restricting ownership of media channels by politicians, and the eradication of criminal defamation provisions. Indonesia's continuing progress towards a democratic press will rest largely on the legislature's decision to curb or pragmatically facilitate the rights of journalists to express free speech.

\footnotetext{
${ }^{100}$ Hosen, above n 11, 153.

101 'Jokowi told not to mess with press freedom’, above n 100.

102 Constitutional Court Decision No 012- 022/PUU-IV/2006.
} 


\section{REFERENCES}

\section{ARTICLES / BOOKS / REPORTS}

Freedom House, Freedom of the Press: Indonesia

$<\underline{\text { https://freedomhouse.org/repor }}$ t/freedom-

press/2012/indonesia >

Freedom House, Freedom of the Press: Indonesia

$<$ https://freedomhouse.org/repor t/freedom-

press/2015/indonesia>

Hosen, Nadirsyah, 'Human rights and press freedom' in Nadirsyah Hosen, Human Rights, Politics and Corruption in Indonesia: a critical reflection on the post Soeharto Era (Dordrecht 2010) 141

Hung, Chen-Ling, 'Media Control and Democratic Transition: Ongoing Threat to Press Freedom in Taiwan', (2013) 9(2) China Media Research 83

Human Rights Watch, Turning Critics into Criminals: the human rights consequences of criminal defamation in Indonesia (3 May 2010)

$<$ https://www.hrw.org/report/20 10/05/03/turning-criticscriminals/human-rightsconsequences-criminaldefamation-law>

Mishra, Naveen K, 'Governmental Threats for Media Freedom: comparative study of Asian countries' (2008) 69(1) The Indian Journal of Political Science 149
Royan, Naomita, 'Increasing Press Freedom in Indonesia: the Abolition of the Lese Majeste and 'Hate-Sowing Provisions' (2008) 10 Australian Journal of Asian Law 291

Sangsuvan, Kitsuron, 'Balancing Freedom of Speech on the Internet Under International Law’ (2014) 39 North Carolina Journal of International Law and Commercial Regulation 701

Tapsell, Ross, 'Old Tricks in a New Era: Self-Censorship in Indonesian Journalism' (2012) 36 Asian Studies Review 227

Tapsell, Ross, 'Politics and Press in Indonesia’ (2012) 39(2) Media Asia 109

The United Nations, The Universal Declaration of Human Rights $<$ http://www.un.org/en/universa l-declaration-human-rights/>

The United Nations, United Nations Member States $<$ http://www.un.org/press/en/20 06/org1469.doc.htm>

The United Nations Treaty Collection, International Covenant on Civil and Political Rights $<$ https://treaties.un.org/Pages/Vi ewDetails.aspx?src=IND\&mtds $\mathrm{g}$ no=IV$\underline{4 \& \text { chapter }=4 \& \text { lang }=\text { en }>}$

\section{CASES}

Constitutional Court Decision No 012022/PUU-IV/2006

Constitutional Court Decision No 6/PUU-V/2007 
Handyside v United Kingdom (1976) 24

ECHR (ser. A) 23

\section{LEGISLATION}

The Indonesian Criminal Code (Kitab Undang-undang Hukum Pidana)

The 1945 Constitution of the Republic of Indonesia

Law No 5/1969 of the Republic of Indonesia on Subversion

Law No 9/1998 of the Republic of Indonesia on Freedom of Expression

Law No 39/1999 of the Republic of Indonesia on Human Rights

Law No 40/1999 of the Republic of Indonesia on the Press
Law No 12/ 2005 of the Republic of Indonesia on the Confirmation (Pengesahan) of the International Covenant on Civil and Political Rights

Law No 11/2008 of the Republic of Indonesia on Electronic Information and Transaction

Stipulation made by the National Assembly of the Consultative Council of the Republic of Indonesia No. XVII/MPR/1998 on Human Rights

\section{TREATIES}

The International Covenant on Civil and Political Rights ('ICCPR') GA res 2200A, UN GOAR, $21^{\text {st }}$ sess, Supp No (16) 52, UN Doc A/6316 (1966)

The Universal Declaration of Human Rights ('UDHR'), GA Res 217A (III) UN GAOR, $3^{\text {rd }}$ sess, $183^{\text {rd }}$ plen mtg, UN Doc A/810 (10 December1948) 